\title{
Analisa Kasus Peran Penyuluh Swadaya Dalam Pengembangan Budidaya Minapadi di Desa Nogotirto
}

\author{
Purwito Zanuar Rahmadi ${ }^{1}$, Ahmad Zuber, Mahendra Wijaya \\ Universitas Sebelas Maret Surakarta
}

\begin{abstract}
The purpose of this study was to determine the role of self-help instructors in developing minapadi cultivation in Nogotirto Village. Agriculture is the main sector that still dominates the livelihoods of the Indonesian population. Agricultural innovation is very necessary to improve the quality and quantity of agricultural products. The results showed that Sawadaya Extension was able to provide innovative breakthroughs to provide solutions to problems that are often faced by farmers through cultivation of Minapadi. Self-help instructors in Latency (Maintenance Pattern) to maintain a system can run according to its structural functions. So, it has become a joint task in a working system in the Sleman Minapadi Community group and the Sleman Fishery Network Network (JMP) to maintain and maintain the patterns that are already very strong the role of self-supporting instructors because it is part of the functional structural system in the group that is.
\end{abstract}

Keywords : Self-supporting Instructors, Latency, and Minapadi.

\begin{abstract}
Abstrak
Tujuan penelitian ini adalah untuk mengetahui peran penyuluh swadaya dalam pengembangan budidaya minapadi di Desa Nogotirto. Pertanian merupakan sektor utama yang masih mendominasi mata pencarian penduduk Indonesia. Inovasi pertanian sangat perlu untuk meningkatkan kualitas dan kuantitas hasil pertanian. Hasil penelitian menunjukkan, Penyuluh Sawadaya mampu untuk memberikan terobosan inovasi untuk memberikan solusi permaalahan yang sering dihadapi petani melalui budidaya minapadi. Penyuluh swadaya dalam Latency (Pemeliharaan Pola) untuk menjaga sebuah sistem dapat berjalan sesuai pada fungsi strukturalnya. Maka, sudah menjadi tugas bersama dalam satu sistem kerja dalam kelompok Komunitas Minapadi Sleman dan JMP (Jaringan Mitra Perikanan) Sleman untuk menjaga dan memelihara pola-pola yang sudah berjalan sangat kuat peran dari penyuluh swadaya karena merupakan bagian dari sistem struktural fungsional yang ada pada kelompok tersebut.
\end{abstract}

Kata Kunci : Penyuluh Swadaya, Latency, dan Minapadi.

\footnotetext{
${ }^{1}$ purwitozanuar@student.uns.ac.id
} 
Analisa Kasus Peran Penyuluh Swadaya Dalam Pengembangan Budidaya Minapadi di Desa Nogotirto

\section{Pendahuluan}

Sektor pertanian merupakan sektor vital bagi kedaulatan suatu bangsa. Karena kebutuhan pangan warga negaranya dicukupi dari hasil sektor pertanian. Bagi Negara seperti Indoensia yang mayoritas penduduknya bekerja pada sektor ini. Invosasi untuk meningkatkan kualitas dan kuantitas hasl produk pertanian menjadi sangat penting. Menurut BPS Menurut Badan pusat Statistik (BPS) Indonesia dalam sensus pertanian tahun 2003, jumlah Rumah tangga petani 31,17 juta. Jumlah tersebut menurun menjadi 26,13 juta rumah tangga petani di tahun 2013. Diikuti menyempitnya luas tanah pertanian yang dikuasai petani, yaitu sekitar 0,3 hektar/RT (BPS, 2013). Berkurangnya Rumah tangga petani, menjadi indikasi bahwa sektor pertanian mulai ditinggalkan karena tidak mampu lagi diandalkan. Menurunnya rumah tangga petani yang diikuti menyempitnya luas lahan pertanian akibat alih fungsi lahan, menyebabkan semakin tingginya arus urbanisasi dan menjadi faktor tingginya ketimpangan sosial.

Salah satu upaya untuk meningkatkan kualitas dan peningkatan hasil produksi pertanian melalui Permentan No. 61/Permentan/Ot.140/11/2008 dikukuhkan hadirnya Penyuluh swadaya. Menurut syahyuti (2014) Penyuluh swadaya adalah pelaku utama pertanian sesuai dengan bidangnya. Selain bertani, sebagian juga menjadi pelaku usaha di bidang pemasaran hasil pertanian, maupun pengadaan sarana produksi. Penyuluh swa-daya umumnya aktif pada beberapa organisasi petani, baik pada Kelompok Tani, Gapoktan, maupun Koperasi dan Badan Usaha Milik Petani (BUMP). Mereka adalah tokoh petani setempat yang bergerak langsung di lahan namun juga memiliki bisnis yang berkaitan dengan pekerjaannya. Beberapa sisi keunggulan penyuluh swadaya dibanding dengan penyuluh peme-rintah dan penyuluh swasta adalah: pertama, lebih mampu menciptakan penyuluhan yang partisipatif. Ini karena penyuluh swadaya hidup di antara petani, mengalami secara langsung perasaan dan masalah petani, menjadi bagian dari semangat petani, serta terlibat secara partisipatif dalam kegiatan pertanian di komunitasnya. Ia adalah orang dalam yang tidak perlu lagi belajar psikologi petani dan sosiologi masyarakat desa. 
Penyuluh swadaya bertujuan untuk membantu petani dalam menyelesaikan kendala yang menghambat kualitas dan produktifitas hasil pertanian. Salah satu cara yang dilakukan oleh penyuluh swadaya dengan melakukan inovasi pertanian melalui budidaya minapadi di Desa Nogotirto. Budidaya minapadi yang diterapkan adalah suatu cara budidaya ikan dan tanaman padi pada satu lahan yang sama. Minapadi merupakan salah satu bentuk tumpang sari pemeliharaan padi di sawah bersama-sama dengan pemeliharaan ikan. Pada dasarnya sistem ini cukup baik dan tidak membutuhkan banyak biaya (Tim Lentera, 2002; Ampri, dan Khairuman, 2008). Pemeliharaan ikan dengan sistem minapadi ini disesuaikan dengan umur tanaman padi dan tujuan pemeliharaan ikan untuk pendederan atau untuk pembesaran (Tiku, 2008). Dalam perkembangannya sistem minapadi ini mengalami beberapa variasi dalam penerapannya, diantaranya: i) sistem minapadi yang dikelola secara organik dengan penanaman azolla (Sutanto, 2002; Hermawan dan Setiawan, 2010).

Menurut Ritzer (2012) pengembangan teori sosial mampu menjawab persoalan pada masyarakat terutama terkait patologi sosial, pendidikan, politik dan juga ekonomi. Ketika salah satu kebutuhan tersebut tidak terpenuhi atau tidak tercukupi maka akan memunculkan beragam patologi sosial dalam masyarakat. Dalam kehidupan masyarakat terdapat struktur sosial yang dapat difungsikan untuk menimalisir patologi sosial. Pengembangan inovasi minapadi di desa Nogotirto, kondisi pada observasi penelitian ditemukan hanya sedikit petani yang mampu dan berinisiatip untuk menerapkan pertanian berbasis mina padi. Sistem pertanian mina padi merupakan konsep pertanian yang menggabungkan pertanian dan perikanan air tawar pada satu petak sawah. Peran penyuluh swadaya dengan keuletanya untuk menerapkan inovasi pertanian budidaya minapadi oleh petani di Desa Nogotirto tersebut, menjadi dasar minat peneliti untuk melakukan kajian tentang pertanian minapadi. Bagimana dinamika pertanian organik di desa Nogotrito. Bagimana upaya petani untuk mengembangkan pertanian berbasis minapadi, disaat petanipetani lain di Desa Nogotirto masih menggunakan pupuk kimia dan pestisida dalam pertaniannya. Untuk menganalisa masalah tersebut akan dianalisis ke dalam teori 
Analisa Kasus Peran Penyuluh Swadaya Dalam Pengembangan Budidaya Minapadi di Desa Nogotirto

Talcott Parsons. Talcott Parsons salah satu tokoh sosiologi Amerika yang sangat terkenal mengemukan teori tentang AGIL Fungsi dikaitkan sebagai segala kegiatan yang diarahkan kepada memenuhi kebutuhan atau kebutuhan-kebutuhan dari sebuah sistem yang berisi empat persyaratan mutlak yang harus ada supaya termasuk masyarakat bisa berfungsi. Keempat persyaratan tersebut yakni: Adaption, Goal Attainment, Integration, dan Latency (Parsons, 1985).

Menurut Parsons, bahwa sistem sosial terdapat beberapa unsur sosial saling berhubungan satu sama lain yang saling mempengaruhi. Parsons (2013) menjelaskan bahwa (Adaptation) yaitu sistem sosial mampu beradaptasi dengan lingkungan sekitar serta menyesuaikan dengan kebutuhan kelompok. Selain itu juga masyarakat saling memahami dalam mencapai tujuan yang sama (Goal attainment), sehingga terdapat hubungan (Integration) yang erat antara masyarakat, kemudian menjaga pola-pola hubungan (Lattent Pattern Maintance) tersebut. Semuanya saling keterkaitan dan memiliki hubungan satu sama lain dalam sistem sosial. Adaptasi dilakukan dengan cara menjalankan fungsi menyesuaikan diri dengan lingkungan eksternal. Goal attainment difungsikan atas kepribadian memobilisasi sumber daya dan sistem untuk mencapai tujuan. Kemudian menjalankan serta menjaga pola-pola dengan norma dan nilai dalam bertindak.

\section{Metode penelitian}

Penelitian ini menggunakan metode Penelitian kualitatif menggunakan pendekatan studi kasus Pada Peran Penyuluh Swadaya Dalam Pengembangan Budidaya Minapadi di Desa Nogotirto. Teknik pengumpulan data dengan observasi, wawancara mendalam, dan dokumentasi. Untuk validitas data dengan multisumber bukti tidak hanya pada sumber tunggal. Analisis data dengan model interaktif yaitu mereduksi data, menyajikan serta penarikan simpulan (Miles, Huberman and Saldana 2013; Yin, 2017). 


\section{Hasil dan Pembahasan}

\section{Hasil Penelitian}

Dalam upaya meningkatkan kualitas dan kuantitas hasil pertanian, diperlukan suatu inovasi di bidang pertanian. Inovasi usaha dibidang pertanian di Desa Nogotirto, yaitu usaha budidaya perikanan yang terintegrasi dengan pertanian atau disebut dengan istilah "minapadi". Budidaya minapadi dapat menjadi salah satu alternatif cara untuk meningkatkan hasil sawah secara ekonomis. Budidaya minapadi merupakan perpaduan antara bididaya tanaman padi yang dikolaborasikan dengan budidaya perikanan. Model penanaman dan pemeliharaannya menggunakan pola tanam organik atau budidaya pangan sehat.

Budidaya minapadi telah banyak memberikan manfaat dalam meningkatkan pendapatan petani, menahan alih fungsi lahan pertanian. Budidaya minapadi juga mampu menyerap tenaga kerja dan menambah lahan prosuksi ikan guna mencapai target produksi ikan lokal. Keuntungan bagi petani minapadi adalah keuntungan panen ganda dari ikan dan padi. Budidaya minapadi sebagai budidaya pangan sehat, berupaya menjadi dasar petani untuk mengarahkan pada pola-pola perlakuan pertanian organik merupakan salah satu budidaya tanaman dengan menggunakan bahan-bahan yang diperoleh atau dihasilkan secara alami tanpa campuran pupuk kimia dan penggunaan pestisida kimia industri. Pertanian organik merupakan ssuatu cara dalam. produksi pertanian yang belandaskan daur ulang secara hayati. Mendaur ulang unsur hara dapat melalui sarana limbah tanaman dan ternak, serta limbah lainnya yang mampu memperbaiki status kesuburan dan struktur tanah. Pendaur ulangan limbah bertujuan untuk mengembalikan semua jenis bahan organik ke dalam tanah, baik dalam bentuk residu dan limbah pertanaman maupun ternak yang selanjutnya bertujuan memberikan makanan pada tanaman. Pertanian organik mempunyai prinsip-prinsip memberikan makanan pada tanah yang selanjutnya tanah menyediakan makanan untuk tanaman dan bukan memberi makanan langsung pada tanaman. 
Analisa Kasus Peran Penyuluh Swadaya Dalam Pengembangan Budidaya Minapadi di Desa Nogotirto

Pertanian Minapadi di Desa Nogotirto, merupakan pertanian dengan kombinasi perikanan air tawar yang dipelihara dalam satu lahan pertanian. Penerapan pertanian organik minapadi di Desa Nogotirto kurang diminati oleh para petani. Sehingga, di lahan pertanian di Desa Nogotirto hanya tiga petani yang menerapkan pertanian organik minapadi. Proses persiapan lahan untuk pertanian organik minapadi dinilai masih terlau rumit, karena harus mempersiapkan caren (parit di sekeliling sawah) untuk tempat tinggal ikan.

Bahwa pertanian minapadi di Desa Nogotirto, membutuhkan pengelolaan waktu yang panjang. Sinergisitas petani dalam pengelolaan berkelanjutan untuk menjaga unsur hara tanah agar dapat dimanfaatkan untuk dua budidaya sekaligus antara padi dan ikan air tawar. Karena tidak dipergunakannya pupuk maupun pestisida kimia (anorganik), dan murni hanya mengandalkan siklus hidup ekosistem di lingkungan lahan pertanian terutama pada ikan air tawar dan padi sebagai pokok utama budidaya.

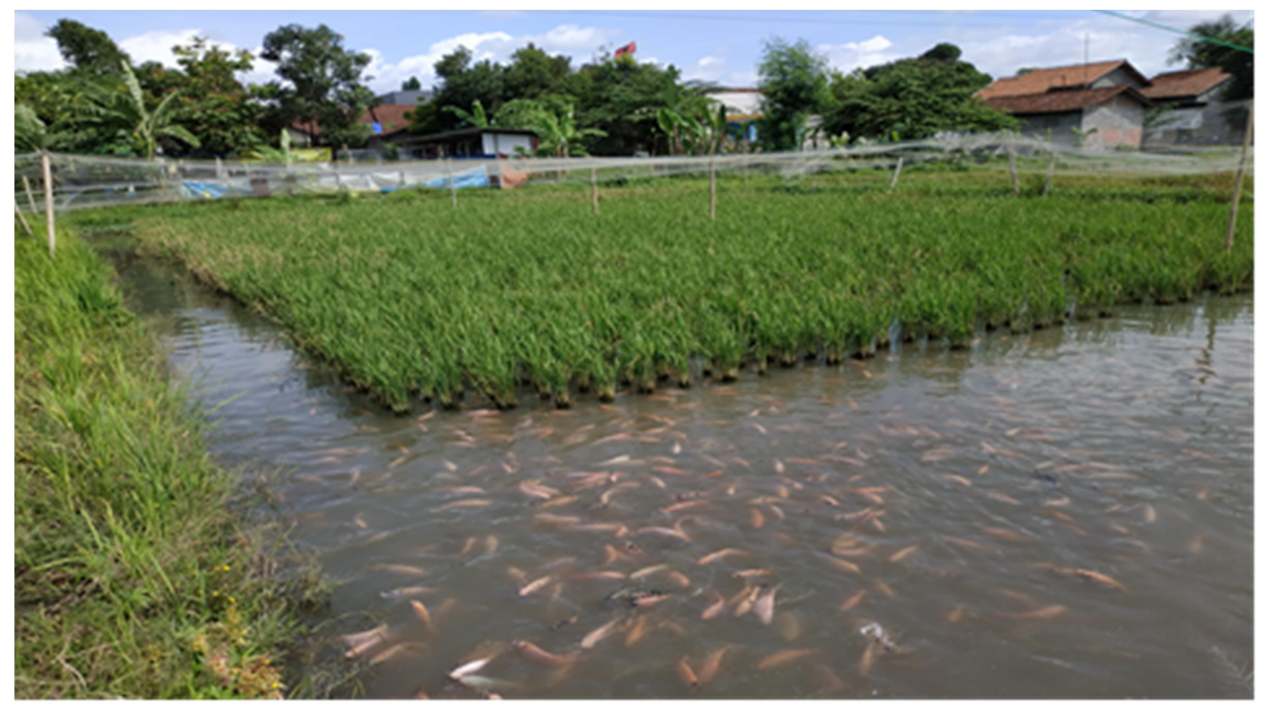

Gambar 1. Lahan Minapadi Desa Nogotirto. (Sumber: Dokumentasi penelitian, Desember 2018).

Tahapan Pertanian Mina padi di Desa Nogotirto, dimulai dengan persiapan lahan pertanian yang di desain berbeda daripada pertanian konvensional. Selain 
melakukan persiapan lahan untuk penanaman padi, petani juga mempersiapkan lahan pertanian untuk tempat budidaya ikan air tawar. Sehingga, lahan pertanian tidak semua tempat ditanami padi. Petani memperdalam pada bagian pinggir lahan pertanian yang berfungsi sebagai tempat (kolam) ikannya. Bahwa, pertanian organik minapadi di Desa Nogotirto dalam persiapan lahan pertanian tidak memaksimalkan luas lahan untuk ditanami padi. Tetapi, lahan pertanian harus disiapkan juga untuk kolam ikan air tawar dengan cara mengsongkan sebagian kecil lahan dari tanaman padi. Supaya ikan air tawar yang dibudidayakan mempunyai rumah atau tempat gerak di dalam air.

\subsection{Potensi Minapadi Di Desa Nogotirto}

\section{a. Daya dukung lingkungan untuk budidaya minapadi}

Faktor lingkungan merupakan suesuatu yang penting dalam proses budidaya pertanian. Terutama, dalam budidaya pertanian minapadi. Syarat yang harus dipenuhi untuk keberhasilan budidaya minapadi adalah lahan pertanian yang subur, serta ketersediaan air yang melimpah untuk hidup ikan budidaya. Desa Nogotirto merupakan suatu kawasan pedesaan yang mempunyai ketersediaan air melimpah setiap tahun.

Bahwa, daya dukung lingkungan sangat berperan dalam proses budidaya pertanian minapadi yang ada di Desa Nogotirto. Hal ini tidak lepas dari Potensi kesuburan lahan pertanian, yang didukung oleh ketersediaan air irigasi yang melimpah di Desa Nogotirto.

\section{b. Pemasaran Hasil Panen Ikan Budidaya Minapadi}

Pemasaran hasil panen merupakan ujung tombak dari rangkaian akhir proses budidaya ikan yang dilakukan petani minapadi Desa Nogotirto. Dengan tersedianya pasar khusus ikan yang bertujuan untuk memudahkan akses penjualan para petani ikan di Desa Nogotirto. Bahkan juga menerima 
Analisa Kasus Peran Penyuluh Swadaya Dalam Pengembangan Budidaya Minapadi di Desa Nogotirto

suplai ikan dari wilayah lain disekitar Kabupaten Sleman. Terutama, hasil panen ikan dari anggota kelompok JMP (Jaringan Mitra Perikanan) Sleman.

Hasil panen ikan dari minapadi di Desa Nogotirto dipasarkan di pasar ikan Mina Nogotirto yang terletak di Padukuhan Kwarasan. Hasil panen ikan minapadi dalam pemasaran tidak memiliki perbedaan dengan ikan yang dibudidayakan pada kolam pembesaran. Semua ikan hasil panen minapadi dijual dengan mekanisme harga pasar yang berlaku saat itu. Harga ikan hasil panen dijual di pasar ikan Mina Nogotirto dengan harga sekitaran \pm Rp23.000,00. Panen ikan minapadi di Nogotirto biasanya dilakukan pada saat setelah dua minggu setelah panen padi dilakukan, dan diwaktu sore hari.

Bahwa, pemasaran ikan air tawar masih sangat potensi untuk memenuhi kebutuhan ikan air tawar di sekitara wilayah Yogyakarta. Terutama, untuk kebutuhan ikan air tawar di Kota Yogyakarta. Dengan, adanya pasar ikan dan jaringan mitra perikanan yang diikuti petani ikan akan mempermudah dalam memasarkan ikan hasil panen dari minapadi miliknya.

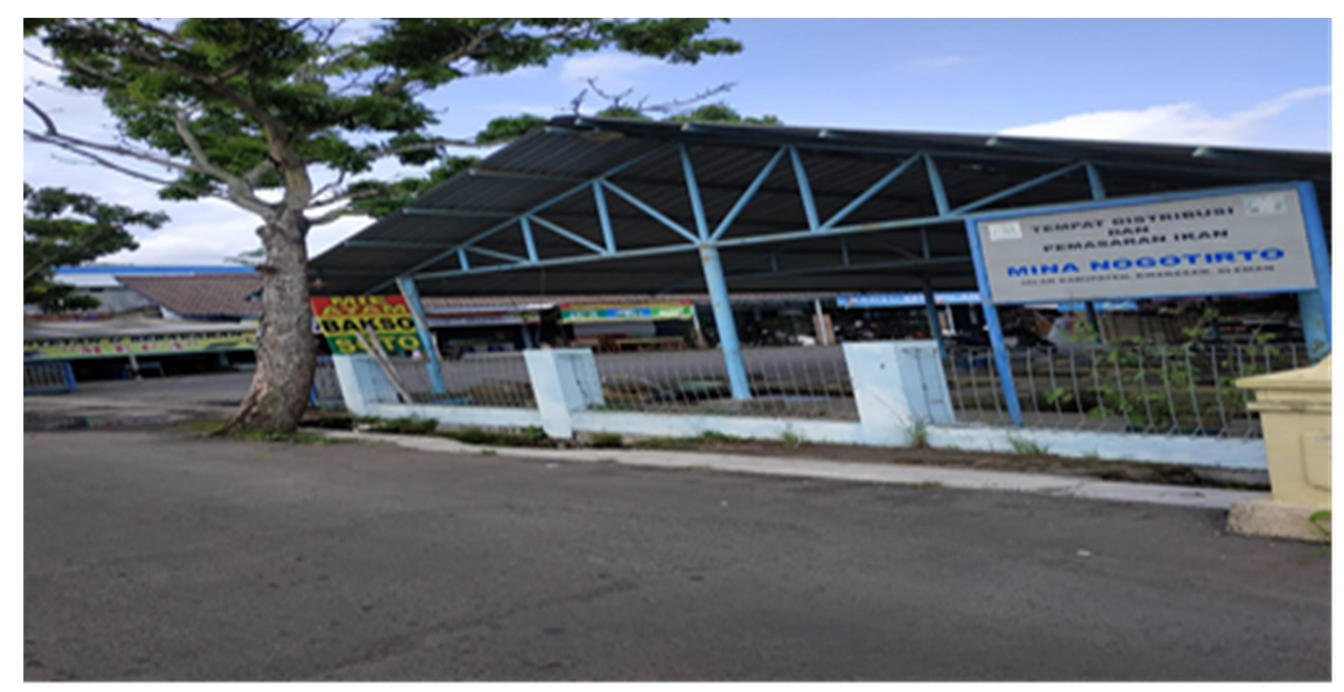

Gambar 2 Pasar Ikan Mina Nogotirto. (sumber: Dokuemntasi penelitian,

Desember 2018). 


\subsection{Faktor penghambat Minapadi di Desa Nogotirto}

\section{a. Air irigasi yang mulai tercemar}

Air irigasi merupakan kebutuhan utama dalam kegiatan pertanian maupun budidaya ikan air tawar. Karena, kebutuhan pengairan diperoleh melalui air irigasi dari Selokan Mataram yang mengalir sampai ke Desa Nogotirto. Perkembangan wilayah Desa Nogotirto yang banyak berubah menjadi perumahan dan perkantoran, berdampak pada kuaitas air irigasi pertanian yang ada di Desa nogotirto. Selokan atau parit perumahan sebagai buangan limbah rumahtangga yang menyatu dengan jalur irigasi pertanian berdampak pada air irigasi yang tercemar. Padahal air irigasi pertanian inilah yang digunakan untuk pengairan lahan pertanian dan perikanan di Desa Nogotirto. Air irigasi sebagai potensi Desa Nogotirto yang mulai tercemar, membuat perkembangan pertanian organik minapadi sulit untuk dikembangkan supaya diaplikasikan ke petani lain di Desa Nogotirto.

\section{b. Pemasaran beras/padi dari budidaya minapadi}

Berbanding terbalik dengan pemasaran ikan, pemasaran hasil panen merupakan ujungtombak dari rangkaian akhir proses budidaya organik minapadi yang dilakukan petani minapadi Desa Nogotirto. Harga gabah/beras dari pertanian organik minapadi masih disamakan dengan pertanian konvensional masih menjadi kendala yang dialami petani organik minapadi di Desa Nogotirto. Masyarakat secara umum masih terlalu awam dengan padi organik, serta masyaarakat sebagai konsumen beras lebih memilih beras premiun di pasar yang lebih murah harganya. Hasil pertanian yang dihasilkan di Desa Nogotirto masih ditentukan oleh harga yang ditetapkan pasar melalui pedagang pengepul. Petani hanya mempunyai dua pilihan yaitu menyimpan untuk keperluan sendiri, atau menjual dengan harga yang telah ditentukan pedagang pengepul. 
Petani di Desa Nogotirto dalam pengelolaan hasil panen yang kurang optimal, membuat petani mendapatkan untung kecil dan jauh dari kemakmuran. Petani tidak dapat bersaing harga di pasaran sehingga mereka lebih memilih cara mudah yaitu percaya kepada pedagang pengepul. Karena, lemahnya nilai tawar petani terhadap pasar, membuat petani menaruh sikap skeptis pada pertanian di Nogotirto. hal inilah yang membuat inovasi pertanian organik juga terhambat dalam pelaksanaannya.

\section{c. Bertani bukan pekerjaan utama masyarakat di Desa Nogotirto}

Bekerja di sektor pertanian di Desa Nogotirto bukanlah pekerjaan utama masyarakat. Masyarakat Desa Nogotirto lebih banyak bekerja di luar Desa Nogotirto. Karena pekerjaan di luar sektor pertanian yang jauh lebih besar membuat Sektor pertanian di Nogotirto menjadi sulit perkembang. Sektor pertanian dikerjakan ibarat sebagai pengisi waktu luang atau hobi untuk menambah pendapatan keluarga di sela-sela waktu luang bekerja di Kota. Karena kehidupan masyarakat Desa Nogotirto yang sudah cenderung memilih bekerja ke luar Desa. Sehingga, petani dalam upaya inovasi pertaniannya menjadi rendah. Petani lebih memilih untuk menggunakan cara-cara yang sudah ada dan dianggap lebih praktis dan efisien hemat waktu.

\section{Pembahasan}

Talcott Parsons mengemukakan dalam teori AGIL yang dapat dikaitkan dengan kegiatan yang diarahkan pada pemenuhan kebutuhan dari sebuah sistem. Terdapat empat persyaratan mutlak supaya masyarakat bisa berfungsi. Keempat persyaratan tersebut yakni Adaption, Goal Attainment, Integration, dan Latency. Demi keberlangsungan hidupnya, maka masyarakat harus menjalankan fungsifungsi tersebut (Ritzer, 2010). 
Pertama, Adaptasi (adaptation) dalam upaya merawat sebuah sistem sehingga mampu untuk beradaptasi dengan situasi ekternal. Sistem harus dapat menyesuaikan diri dengan lingkungan sekitar juga dalam menghadapi perubahan sosial. Keberadaan penyuluh swadaya yang mampu menciptakan inovasi usaha dibidang pertanian dalam penerapan minapadi. Sehingga, membuka peluang petani untuk mengadaptasi pola-pola budidaya yang sudah dibuktikan oleh penyuluh swadaya melalui demplot (demontrasi plot).

Kedua, Pencapaian tujuan (goal attainment) merupakan suatu sistem usaha yang dijalankan oleh penyuluh swadaya memiliki tujuan (misi) yang jelas dan pasti sebab hal ini menjadi kunci dalam mencapai target suatu usaha (Becherer, dkk, 2012). Tujuan dari penyuluh swadaya di Desa Nogotirto adalah untuk memberikan edukasi dan penyadaran kepada petani bawah inovasi pertanian itu perlu guna kesejahteraan petani itu sendiri. Sehingga, petani dapat bertahan dan mampu mandiri.

Ketiga, Integrasi (integration), Penyuluh Swadaya dapat mengintegrasikan antara peran kerja dengan program inovasi pertanian budidaya minapadi. Sehingga, mampu menyatukan ke dalam sistem kerja, dan membantu mengatasi kelamahan dari porgram inovasi budidaya minapadi yang sedang dilakukan. Penyuluh swadaya mengintegrasikan kerja dan program inovasi pertanian budiaya minapadi ke dalam bentuk komunitas Minapadi Sleman dan Koperasi JMP (Jaringan Mitra Perikanan) Sleman sebagai tugas memnatu pemasaran hasil perikanan budidaya.

Keempat, Latency (Pemeliharaan Pola) untuk menjaga sebuah sistem dapat berjalan sesuai pada fungsi strukturalnya. Maka, sudah menjadi tugas bersama dalam satu sistem kerja dalam kelompok Komunitas Minapadi Sleman dan JMP (Jaringan Mitra Perikanan) Sleman untuk menjaga dan memelihara pola-pola yang sudah berjalan. Dengan berjalannya pola ini menjadi sebuah dasar bagi keberhasilan suatu usaha. Pemeliharaan pola pada kelompok kerja Komunitas Minapadi dan JMP (Jaringan Mitra Perikanan) Sleman cukup berjalan baik dengan berjalan sesuai struktur fungsional baik di tingkat budidaya minapadi maupun pada tingkat 
pemasaran. Walaupun, kemampuan kelompok untuk memenuhi permintaan pasar terhadap komoditas perikanan masih kurang mampu dilakukan. Sehingga, perlu untuk membentuk suatu tata sistem struktural maupun fungsional untuk meningkatkan kinerja anggota kelompok dalam komunitas minpadi sleman dan JMP (jaringan Mitra Perikanan) Sleman, serta mendorong petani-petani lain supaya tertarik untuk bergabung dalam menerapkan budidaya minapadi (Kelly \& Dorian, 2017).

\section{Kesimpulan}

Berdasarkan uraian yang telah dikemukakan dalam hasil penelitian data dan analisa yang telah diperoleh, maka dapat disimpulkan bahwa analisa kasus Analisa Kasus Peran Penyuluh Swadaya Dalam Pengembangan Budidaya Minapadi di Desa Nogotirto mampu menciptakan kelompok kerja melalui Komunitas Minapadi Sleman dan JMP (Jaringan Mitra Perikanan) Sleman. Penyuluh Sawadaya mampu untuk memberikan terobosan inovasi untuk memberikan solusi permaalahan yang sering dihadapi petani melalui budidaya minapadi. Penyuluh swadaya dalam Latency (Pemeliharaan Pola) untuk menjaga sebuah sistem dapat berjalan sesuai pada fungsi strukturalnya. Maka, sudah menjadi tugas bersama dalam satu sistem kerja dalam kelompok Komunitas Minapadi Sleman dan JMP (Jaringan Mitra Perikanan) Sleman untuk menjaga dan memelihara pola-pola yang sudah berjalan sangat kuat peran dari penyuluh swadaya karena merupakan bagian dari sistem struktural fungsional yang ada pada kelompok tersebut. 


\section{Daftar Pustaka}

Ampri., K, dan Khairuman. 2008. Budidaya Ikan Nila Secara Intensif. Jakarta: Agromedia Pustaka.

Becherer, RC. Helms, MM. McDonald, JP. 2012. The Effect of Entrepreneurial Marketing on Outcome Goals in SMEs. New England Journal of Entrepreneurship, 15(1): 7-18

Data Badan pusat Statistik (BPS) Indonesia dalam sensus pertanian tahun 2013

Miles, M, B. Huberman, M, A. Saldana, J. 2013. Qualitative Data Analysis: A Methods Sourcebook. California: Sage Publication.

Parsons, T. (1985). Talcott Parsons on institutions and social evolution: selected writings. University of Chicago Press.

Parsons, Talcott. 2013. Social System. London. Routledge.

Permentan No. 61/Permentan/Ot.140/11/2008

Ritzer, George. 2012. Teori Sosiologi: Dari Sosiologi Klasik Sampai Perkembangan Terakhir Postmodern. Terj. Saut Pasaribu dkk. Yogyakarta: Pustaka Pelajar..

Sutanto, R. 2002. Pertanian Organik. Kanisius, Yogyakarta.

Syahyuti. 2014. Peran Strategis Penyuluh Swadaya Dalam Paradigma Baru Penyuluhan Pertanian Indonesia. Forum Penelitian Agro Ekonomi, Volume 32 No. 1, Juli 2014: $\quad 43-58$.

Tiku. 2008. Analisis pendapatan usahatani padi sawah menurut sistem minapasi dan sistem non minapadi (Kasus Desa Tapos I dan Desa Tapos II, Kecamatan Tenjolaya, Kabupaten Bogor, Jawa Barat. Skripsi, Program Studi Manajemen Agribisnis, Fakultas Pertanian IPB.

Yin, Robert. K. (2017). Case Study Research and Applications: Design and methods. London. Sage publications. 